\title{
EVALUATION OF BIOREMEDIATION OF OIL-POLLUTED SOIL USING THE RESPIROMETRIC OXITOP® METHOD.
}

\author{
Aare Selberg \\ Toomas Tenno \\ University of Tartu, Estonia
}

\begin{abstract}
Bioremediation includes natural processes to degrade harmful compounds in the environment. The goal in bioremediation is to stimulate microorganisms with different additives that will activate them to destroy the contaminants. Respirometry methods have been used to assess the microbial activity of soil but a few respirational studies have been performed with sirfactants.
\end{abstract}

The objective of this study was to examine the effocts of surfactants and adsorbents on oil-contaminanted soil respirational activity. The measurement of oxygen consumption is used to evaluate the enhancement of the bioremediation of polluted soil by surfactants and adsorbents. Selected surfactants were sodium dodecyl sulfate (SDS), Saponine and emulsifying agent SR-100. In the present study the respirometric OxiTop \&ystem was used to measure the oxygen consumption of the soil by adding the different surfactants. The rates of oxygen consumption were calculated from respiration data.

The measurements of respiration showed that the maximum initial rate of oxygen consumption of soil was $4.39 \mathrm{mg} \mathrm{O}_{2} \mathrm{~kg}^{-1} \mathrm{~h}^{-1}$ at the water content of $9 \%$ (w/w ). SR-100 addition showed the highest initial rate of oxygen consumption $-18.61 \mathrm{mg} \mathrm{O}_{2} \mathrm{~kg}^{-1} \mathrm{~h}^{-1}$. The modium rate of oxygen consumption of the oil contaminated soil for five days was half of the initial rate. The mixtures of soil and the adsorbents had lower respirational activity, even when solutions of the surfactants were added. The highest initial rates of oxygen consumption of soil were $4.24 \mathrm{mg} \mathrm{O}_{2} \mathrm{~kg}^{-1} \mathrm{~h}^{-1}$ (Saponine solution was added) and $13.00 \mathrm{mg} \mathrm{O}_{2} \mathrm{~kg}^{-1} \mathrm{~h}^{-1}$ (SR-100 solution was added) for the hydrophobic and hydrophilic adsorbents, respectively. For the mixture of soil and adsorbent the longer lag-period for the activation of oxygen consumption occurred by the adding of surfactants.

\section{KEYWORDS}

Adsorbents; Bioremediation; OxiTop@; Oxygen consumption; Petroleum hydrocarbons; Respirational activity; Surfactants. 


\section{INTRODUCTION}

Bioremediation is a process by which contaminants are degraded by bacteria and other microorganisms. Bacteria and furgi are the main degraders in soil environments [I]. Several contaminants (e.g. petroleum hydrocarbons) can act as a source of carbon and energy for the growth of soil microorganisms. The primary measure of the success of bioremediation is reduction in the concentration of contaminants and methods of the determination of concentration exhibit high detection limits and are susceptible to various influences $[2,3]$. To assess the results of biological decontamination it is not only sufficient to measure the residual concentration of hydrocarbons in soil. It is essential to measure additionally the microbial activity because not all petroleum hydrocarbons mineralize completely to $\mathrm{CO}_{2}$ during the biodegradation [4]. One of the most common parameter for the observation of the soil microflora is soil respiration measured by the rate of $\mathrm{CO}_{2}$ release or $\mathrm{O}_{2}$ consumption [5]. It can give information on the presence of viable microorganisms as well as on the effects of pollutants on the metabolic activity of soil. Most microorganisms in the soil are dormant, so their rate of respiration is low. Their respiration can be stimulated by adding an easily degradable substrate [6] or by using the surfactants due to increased bioavailability of contaminants [7]. Numerous publications deal with the addition $[7,8]$ or formation of surfactants in the microbial degradation of hydrocarbons $[9,10]$.

The aerobic biodegradability of the contaminants is a critical factor in assessing the environmental fate of contaminants. There are a number of internationally standardized biodegradation test methods in aquatic and soil system [11]. Respirometry methods have been used for many years to assess the microbial activity of mainly heterotrophic bacteria [12]. All respirometers are based on some technique for measuring the respiration rate; i.e. the rate at which microorganisms take up dissolved oxygen (DO) from the soil liquid. This can be done directly by measuring DO (chemically and electrochemically) or indirectly by measuring gaseous oxygen (manometric, volumetric, and paramagnetic methods) [13, 14, 15]. The principle of omanometric oxygen determination is based upon oxygen being consumed by organisms while $\mathrm{CO}_{2}$ is formed at the same time. This latter gas is absorbed by alkali and the change in pressure is attributed to the oxygen consumption only [16].

The objective of this study was to examine the effects of surfactants and adsorbents on oil-polluted soil using manometric respirometer. The measurements of oxygen consumptions of soil were concentrated on the initial phase of soil treatment.

\section{MATERIAL AND METHODS}

\subsection{Soil}

The experiments were carried out with sandy soil containing $2 \%$ of clay. The soil samples were collected from ground surface and stored air-dry at room temperature in plastic containers until needed. The soil had $\mathrm{pH}$ of 7.0 (measured in the solution of $\mathrm{CaCl}_{2}$ ) and contained $1.0 \mathrm{mg} / \mathrm{kg}$ available phosphorus and $0.12 \mathrm{mg} / \mathrm{kg}$ nitrate-nitrogen. The soil contaminated with a mixture of jet fuel, diesel oil and lubricating oils was sampled from 
KALMAR ECO-TECH'03

Bioremediation and Leachate Treatment

KALMAR, SWEDEN, November 25-27, 2003

Ämari airport (northwest Estonia). The content of total petroleum hydrocarbons (TPH) was between 450 and $3800 \mathrm{mg} / \mathrm{kg}$ dry soil. The soil samples used in experiments had $\mathrm{TPH}$ concentration of $1590 \mathrm{mg} / \mathrm{kg}$.

\subsection{Reagents}

In the latter experiments the soil samples were mixed with the porous adsorbents prepared by modifying of the urea-formaldehyde resins. The hydrophobic and hydrophilic adsorbents were added to the soil by $10 \%$ (volume/volume). The adsorbents contained $0.75 \% \mathrm{P}$ and $0.43 \% \mathrm{~N}$.

Soil was treated with solutions of different surfactants. The selected surfactants were sodium dodecyl sulfate (SDS) (Reachim, USSR), Saponine (Saponinum rad. gypsophillae, Chemapol, Czechoslovakia) and emulsifying agent SR-100 (E-Tech, USA). The emulsifying agent SR-100 contained anionic surfactants, $0.24 \%$ phosphorus and $0.49 \%$ nitrogen.

\subsection{Respirometric method}

The respirometric OxiTop $®$ system (WTW, Germany) was used to measure the oxygen consumption of the soil by adding different surfactants and adsorbents. The OxiTop® system offers individual reactors consisting of glass jars with a carbon dioxide trap in the headspace. $1 \mathrm{M}$ solution of sodium hydroxide was used to absorb emitted $\mathrm{CO}_{2}$ [16]. The jars were sealed with a cap containing an electronic pressure indicator (see Figure 1). The measurements of oxygen consumption were carried out at $20^{\circ} \mathrm{C}$ in thermostat cabinet TS 606-G/4 (WTW, Germany). Each reaction vessel contained a known amount of natural soil, typically $40 \mathrm{~g}$. By the results of preliminary experiments $5 \mathrm{~cm}^{3}$ solutions of surfactants were added to the soil samples and oxygen consumption was measured by 5 days. OxiTop® measuring system records 360 data during measuring period and for the period of five days the data were recorded after every 20 minutes.

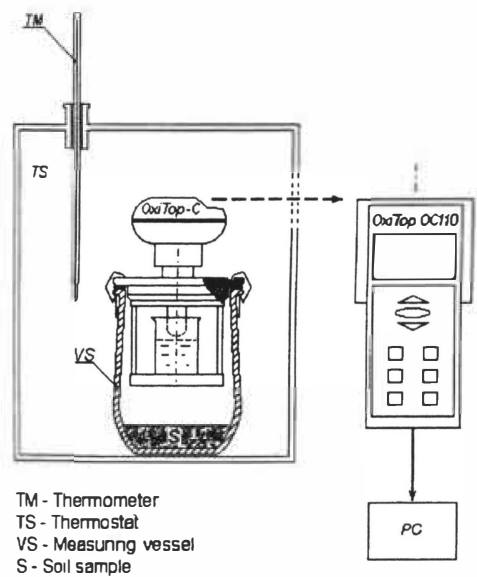

S - Soll sample PC - Computer
Figure 1. The scheme of the OxiTop® apparatus. 


\subsection{Calculation of soil respiration}

The soil respiration was calculated by Equation 1 [16]:

$$
B A=\frac{M_{R}\left(O_{2}\right)}{R \cdot T} \cdot \frac{V_{f r}}{m_{B t}} \cdot \Delta p
$$

$\mathrm{BA}=$ soil respiration [in $\mathrm{mg} \mathrm{O} / \mathrm{kg}$ dry soil]

$\mathrm{M}_{\mathrm{R}}\left(\mathrm{O}_{2}\right)=$ molar mass of oxygen $=32000 \mathrm{mg} / \mathrm{mol}$

$\mathrm{V}_{\mathrm{fr}}=$ free gas volume $[$ in $\mathrm{L}]$

$\mathrm{R}=$ general gas constante $=83.14 \mathrm{~L} \cdot \mathrm{mbar} \cdot \mathrm{mol}^{-1} \cdot \mathrm{K}^{-1}$

$\mathrm{T}=$ measuring temperature $[$ in $\mathrm{K}]$

$\mathrm{m}_{\mathrm{Bt}}=$ mass of dry soil sample in the measuring vessel [in $\left.\mathrm{kg}\right]$

$\Delta \mathrm{p}=$ reduction in pressure of the measuring preparation [in mbar]

For each experiment the "free gas volume" must be known and it is calculated by Equation 2 [16]:

$$
\mathbf{V}_{\text {fr }}=\mathbf{V}_{\text {ges }}-\mathbf{V}_{\mathbf{A G}}-\mathbf{V}_{\mathrm{AM}}-\mathbf{V}_{\mathrm{Br}}
$$

$\mathrm{V}_{\text {ges }}=$ total volume of headspace enclosed in the measuring vessel [in $\left.\mathrm{L}\right]$

$\mathrm{V}_{\mathrm{AG}}=$ characteristic volume of the vessel for the absorbing agent [in $\left.\mathrm{L}\right]$

$\mathrm{V}_{\mathrm{AM}}=$ characteristic volume of the absorbent [in L]

$\mathrm{V}_{\mathrm{Bf}} \in$ volume of moist soil [in L]

\section{RESULTS}

The content of water influenced the respirational activity of the soil sample. By the low respirational activity of soil the experiments with water continued for seven days. The initial and medium rates of oxygen consumption are given in Table 1. The medium rates were calculated for seven days.

Table 1. Influence of water content on the oxygen consumption.

\begin{tabular}{cccc}
$\begin{array}{c}\text { Added water, } \\
\mathrm{g}\end{array}$ & $\begin{array}{c}\text { Water content, } \\
\%\end{array}$ & $\begin{array}{c}\text { Initial rate, } \\
\mathrm{mg} \mathrm{O}_{2} / \mathrm{kg}^{*} \mathrm{~h}\end{array}$ & $\begin{array}{c}\text { Medium rate, } \\
\mathrm{mg} \mathrm{O}_{2} / \mathrm{kg}^{*} \mathrm{~h}\end{array}$ \\
\hline 0 & 1.5 & 2.77 & 0.45 \\
\hline 1 & 3.4 & 3.41 & 1.26 \\
\hline
\end{tabular}


KALMAR ECO-TECH'03

Bioremediation and Leachate Treatment

KALMAR, SWEDEN, November 25-27, 2003

\begin{tabular}{cccc}
\hline 2 & 5.3 & 4.35 & 1.94 \\
\hline 4 & 9.2 & 4.39 & 2.17 \\
\hline 7 & 14.9 & 3.86 & 1.79 \\
\hline 10 & 20.7 & 3.52 & 1.86 \\
\hline 15 & 34.0 & 1.53 & 1.22 \\
\hline 30 & 66.0 & 0.88 & 0.27
\end{tabular}

The rates of oxygen consumption by different surfactants are given in Table 2. The medium rates of oxygen consumption were calculated for 5 days.

Table 2. Influence of surfactants on the oxygen consumption.

\begin{tabular}{cccc} 
Surfactant & $\begin{array}{c}\text { Solution } \\
\text { concentration, } \\
\%\end{array}$ & $\begin{array}{c}\text { Initial rate, } \\
\mathrm{mg} \mathrm{O}_{2} / \mathrm{kg}^{*} \mathrm{~h}\end{array}$ & $\begin{array}{c}\text { Medium rate, } \\
\mathrm{mg} \mathrm{O}_{2} / \mathrm{kg}^{*} \mathrm{~h}\end{array}$ \\
\hline SR-100 & 8 & 18.61 & 6.92 \\
\hline SR-100 & 1.5 & 6.03 & 3.77 \\
\hline SDS & 8 & 12.02 & 12.31 \\
\hline SDS & 1.5 & 9.63 & 5.91 \\
\hline Saponine & 8 & 15.49 & 8.79 \\
\hline Saponine & 1.5 & 5.00 & 1.41
\end{tabular}

The oxygen consumption of the mixture of soil and adsorbents are given in Table 3. The medium rates of oxygen consumption were calculated for 5 days.

Table 3. Influence of adsorbents on the oxygen consumption.

\begin{tabular}{cccc} 
Surfactant & $\begin{array}{c}\text { Solution } \\
\text { concentration, } \%\end{array}$ & $\begin{array}{c}\text { Initial rate, } \\
\mathrm{mg} \mathrm{O}_{2} / \mathrm{kg}^{*} \mathrm{~h}\end{array}$ & $\begin{array}{c}\text { Medium rate, } \\
\mathrm{mg} \mathrm{O}_{2} / \mathrm{kg}^{*} \mathrm{~h}\end{array}$ \\
\hline Hydrophobic adsorbent & 1.57 & 6.19 \\
\hline SR-100 & 8 & 0.45 & 1.25 \\
\hline SDS & 1.5 & 0.15 & 1.78 \\
\hline SDS & 8 & 1.55 & 3.30 \\
\hline Saponine & 1.5 & 1.70 & 9.21 \\
\hline Saponine & 8 & 4.24 & 3.02 \\
\hline & 1.5 & 13.00 & 4.68 \\
\hline SR-100 & Hydrophilic adsorbent & 2.51 \\
\hline SR-100 & 8 & 5.46 & 9.11 \\
\hline SDS & 1.5 & 3.18 & 4.82 \\
\hline SDS & 8 & 0.48 & 6.75 \\
\hline Saponine & 1.5 & 7.28 & 1.52
\end{tabular}




\section{DISCUSSION}

The present study reports the reaction of soil respirational oxygen consumption during the microbial decontamination of oil-polluted soil. The indigenous microorganisms were biostimulated by bioremediation treatnents using different surfactants and adsorbents.

Soil water has two different functions in the bioremediation of polluted soil. It serves as a growth medium for microorganisms. During contaminated soil bioremediation metabolism of soil microorganisms occurs only in the soil aqueous solution. Oxygen must diffuse across the air-water interface to reach the soil aqueous solution where aerobic biodegradation of contaminants occurs [17]. Soil with a higher water content has a greater volume for the micro-organism population. At the same time high water content decreases the oxygen transfer rate in soil matrix and it reduces the respirational oxygen consumption of polluted soil, as indicated in Table 1. The optimal water content for the effective bioremediation of polluted soil depends on the properties of soil and population of microorganisms. In present study $9.2 \%(w / w)$ water content of soil was optimal for respirational oxygen consumption of oil-polluted soil. This water content was achieved by adding $4 \mathrm{~cm}^{3}$ water to $40 \mathrm{~g}$ soil sample.

Preliminary experiments showed that $5 \mathrm{~cm}^{3}$ solutions of surfactants to $40 \mathrm{~g}$ soil sample induced the optimal water content of soil and the highest rate of oxygen consumption of soil was achieved. The concentrations of surfactants $(8 \%$ and $1.5 \% \mathrm{w} / \mathrm{w})$ were chosen by our preliminary experiments with SR-100 [18]. The influence of SR-100 was compared with anionic surfactant SDS and nonionic (and natural) surfactant Saponine (se Table 2). Anionic surfactants are usually chosen for surfactant-based remediation procedure because of their lower degree of adsorption on soil than that by cationic and nonionic surfactants [19]. By results of experiments the initial rates of oxygen consumption of soil were higher by adding of solution of SR-100 containing nutrients in comparison with anionic surfactant SDS. Activation of oxygen consumption by adding the solution of Saponine showed that Saponine as natural surfactant is easily biodegradable and it activates oxygen consumption as additional energy source for microorganisms of soil.

Our preliminary experiments showed that the treatment of soil samples with the solution of SR-100 induced the leaching of hydrocarbons from soil. The hydrocarbons did not leachate from the mixture of soil and adsorbents [18]. The mixing soil with adsorbents reduced the rates of oxygen consumption of soil and the reduction of oxygen consumption was higher by using the hydrophobic adsorbent (see Table 3). Adsorption of water on the hydrophilic adsorbent reduced the water content of soil and the rate of oxygen consumption was lower in comparison with soil sample without adsorbents. Adsorption of petroleum hydrocarbons on the hydrophobic adsorbent reduced the bioavailability of hydrocarbons to microorganisms of soil and the initial rate of oxygen consumption of soil was up to 10 times lower in comparison with using of hydrophilic adsorbents. Adsorption of surfactants can influence the oxygen consumption of soil and the degree of adsorption depends on the properties of the adsorbents and surfactants. Determination of adsorption of surfactants on the adsorbents needs additional research. 


\section{CONCLUSION}

Oxygen consumption is used as a measure for substrate consumption [13]. Oxygen consumption of contaminated soil can be enhanced by adding nutrients and oxygen. Added surfactants increase bioavailability of petroleum hydrocarbons and accelerate biodegradation of hydrocarbons. Soil respirational method should complement chemical methods to evaluating and assessing the success of bioremediation of polluted soil.

\section{ACKNOWLEDGEMENTS}

The authors thank the World Federation of Scientists for support.

\section{REFERENCES}

[1] Balba, M.T., Al-Awadhi, N., Al-Daher, R., 1998, Bioremediation of soil oilcontaminated soil: microbiological methods for feasibility assessment and field evaluation. Journal of Microbiological Methods, 32, 155-164.

DOI: https://doi.org/10.1016/S0167-7012(98)00020-7

[2] Berset, J.D., Ejem,M., Holzer, R., Lischer,P., 1999, Comparison of different drying, extraction and detection techniques for the determination of priority polycyclic aromatic hydrocarbons in background contaminated soil samples. Analyzica Chimica Acta, 383, 263-275.

DOI: https://doi.org/10.1016/S0003-2670(98)00817-4

[3] Dean, J.R., Xiong, G., 2000, Extraction of organic pollutants from environmental matrices: selection of extraction technique. Trends in analytical chemistry, 19, 553-563. DOI: https://doi.org/10.1016/S0165-9936(00)00038-8

[4] Margesin, R., Zimmerbauer, A., Schinner, F., 2000, Monitoring of bioremediation by soil biological activities. Chemosphere, 40, 339-346

DOI: https://doi.org/10.1016/S0045-6535(99)00218-0

[5] Brohon, B., Delolme, C., Gourdon, R., 2001, Complementarity of bioassays and microbial activity measurements for the evaluation of hydrocarbon-contaminated soils quality. Soil Biology and Biochemistry, 33, 883-891.

DOI: https://doi.org/10.1016/S0038-0717(00)00234-0

[6] Lin, Q., Brookes, P.C., 1999, An evaluation of the substrate-induced respiration method. Soil Biology and Biochemistry, 31, 1969-1983. DOI: https://doi.org/10.1016/S0038-0717(99)00120-0

[7] Bardi, L., Mattei, A., Steffan, S., Marzona, M., 2000, Hydrocarbon degradation by a soil microbial population with $\beta$-cyclodextrin as surfactant to enhance bioavailability. Enzyme and Microbial Technology, 27, 709-713.

DOI: https://doi.org/10.1016/S0141-0229(00)00275-1

[8] Mulligan, C.N., Yong, R.N., Gibbs, B.F., 2001, Surfactant-enhanced remediation of contamituated soil: a review. Engineering Geology, 60, 371-380.

[9] DOI: https://doi.org/10.1016/S0013-7952(00)00117-4 Holmberg, K., 2001, Natural surfactants. Current pinion in colloid \& Interface Science, 6, 148-159. 


\section{KALMAR ECO- TECH 03 \\ Bioremodiation and Leachate Treatment \\ KALMAR, SWEDEN, November 25.27, 2003}

[10] Riis, V., Brandt, M., Miethe, D., Babel, W., 2000, Influence of special surfactants on the microbial degradation of mineral oils. Chemosphere, 41, 1001-1006.

DOI: https://doi.org/10.1016/S0045-6535[99]00484-1

[11] Pagga, U., 1997, Testing biodegradability with standardized methods. Chemosphere,35, 2953-2972.

DOI: https://doi.org/10.1016/S0045-6535[97]00262-2

[12] du Plessis, C.A., Barnard, P., Naldrett, K., de Kock, S.H., 2001, Development of respirometry methods to assess the microbial activity of thermophilic bioleaching archaea. Journal of Microbiological Methods, 47, 189-198.

DOI: https://doi.org/10.1016/S0167-7012[01]00300-1

[13] Tzoris, A., Cane, D., Maynard, P., Hall, E.A.H., 2002, Tuning the parameters for fast respirometry. Analytica Chimica Acta, 460, 257-270.

DOI: https://doi.org/10.1016/S0003-2670[02]00190-3

[14] Strotmann, U.J., Schwarz, H.,Pagga, U., 1995, The combined $\mathrm{CO}_{2} / \mathrm{DOC}$ test - a new method to determine the biodegradability of organic compounds. Chemosphere, 30, 525-538.

[15] Reuschenbach, P., Pagga, U., Strotmann, U., 2003, A critical comparison of respirometric biodegradation tests based on OECD 301 and related test methods. Water Research, 37, 1571-1582.

DOI: https://doi.org/10.1016/S0043-1354[02]00528-6

[16] Platen, H., Wine, A., 1999, Measurement of the respiration activity of soils using the OxiTop Control measuring system. Basic principles and process characteristic quantities. Marix: Soils and solids. Applications of analysis no.1, I st edition: Julyl 999.

[17] Li, K.Y., Zhang, Y., Xu,T., 1995, Bioremediation of oil-contaminated soil - a rate odel. Waste Management, 15, 335-338.

DOI: https://doi.org/10.1016/0956-053X[95]00034-W

[18] Selberg, A., Tenno, T., 2003, Bioremediation of oil-contaminated soil using surfactant and adsorbents. In: Procedings of Sixth International Symposium \& Exhibition on Environmental Contamination in Central and Eastern Europe and the Commonwealth of Independent States. 1-4 September 2003, Prague, Czech Republic.

[19] Le, D.-H., Cody, R.D., Kim, D.-J., Choi, S., 2002, Effect of soil texture on surfactant-based remediation of hydrophobic organic-contaminated soil. Environment International, 27, 681-688. DOI: https://doi.org/10.1016/S0160-4120(01)00130-1 